\title{
Attempted Detection of Toxoplasma gondii Oocysts in Environmental Waters Using a Simple Approach to Evaluate the Potential for Waterborne Transmission in the Galápagos Islands, Ecuador
}

\author{
Michelle L. Verant, ${ }^{1}$ Noemi d'Ozouville, ${ }^{2,3}$ Patricia G. Parker, ${ }^{3,4,5}$ Karen Shapiro, ${ }^{6}$ \\ Elizabeth VanWormer, ${ }^{6}$ and Sharon L. Deem ${ }^{3,4,7}$ \\ ${ }^{1}$ University of Wisconsin-Madison, School of Veterinary Medicine, 2015 Linden Dr, Madison, WI 53706 \\ ${ }^{2}$ Galapagos Islands Integrated Water Studies, UPMC-Sorbonne Universités \& CNRS, UMR 7619, Sisyphe, France \\ ${ }^{3}$ Charles Darwin Foundation, Santa Cruz, Galápagos, Ecuador \\ ${ }^{4}$ University of Missouri-St. Louis, St. Louis, MO \\ ${ }^{5}$ WildCare Institute, Saint Louis Zoo, St. Louis, MO \\ ${ }^{6}$ University of California-Davis, School of Veterinary Medicine, One Health Institute, Davis, CA \\ ${ }^{7}$ Institute for Conservation Medicine, Saint Louis Zoo, St. Louis, MO
}

\begin{abstract}
Toxoplasmosis is a health concern for wildlife and humans, particularly in island ecosystems. In the Galápagos Islands, exposure to Toxoplasma gondii has been found in marine avifauna on islands with and without domestic cats. To evaluate potential waterborne transmission of $T$. gondii, we attempted to use filtration and epifluorescent microscopy to detect autofluorescent $T$. gondii oocysts in fresh and estuarine surface water samples. T. gondii oocyst-like structures were microscopically visualized but were not confirmed by polymerase chain reaction and sequence analyses. Further research is needed to refine environmental pathogen screening techniques and to evaluate disease risk of waterborne zoonoses such as T. gondii for wildlife and humans, particularly in the Galápagos and other naive island ecosystems.
\end{abstract}

Keywords: Toxoplasma gondii, waterborne zoonosis, Galápagos, epifluorescent microscopy

The Galápagos islands attracts nearly 200,000 visitors yearly and human development has contributed to a growing list of challenges for conservation related to population growth, resource consumption, and invasive species (Watkins and Cruz 2007; González et al. 2008). Introduced

Electronic supplementary material: The online version of this article (doi:10.1007/s10393-013-0888-5) contains supplementary material, which is available to authorized users.

Correspondence to: Michelle L. Verant, e-mail: mverant@gmail.com species, such as domestic cats, represent the greatest conservation threat to endemic flora and fauna (Kaiser 2001; Snell et al. 2002). Direct links between domestic cat predation and island species extinctions are well described (Nogales et al. 2004), but the impacts of cat-associated diseases have received less attention.

As the only definitive host for Toxoplasma gondii, felid species play a pivotal role in the introduction and maintenance of the pathogen (Wallace et al. 1972). In the Galápagos Islands, feral domestic cats (Felis catus), which are now ubiquitous on inhabited islands and some areas of 


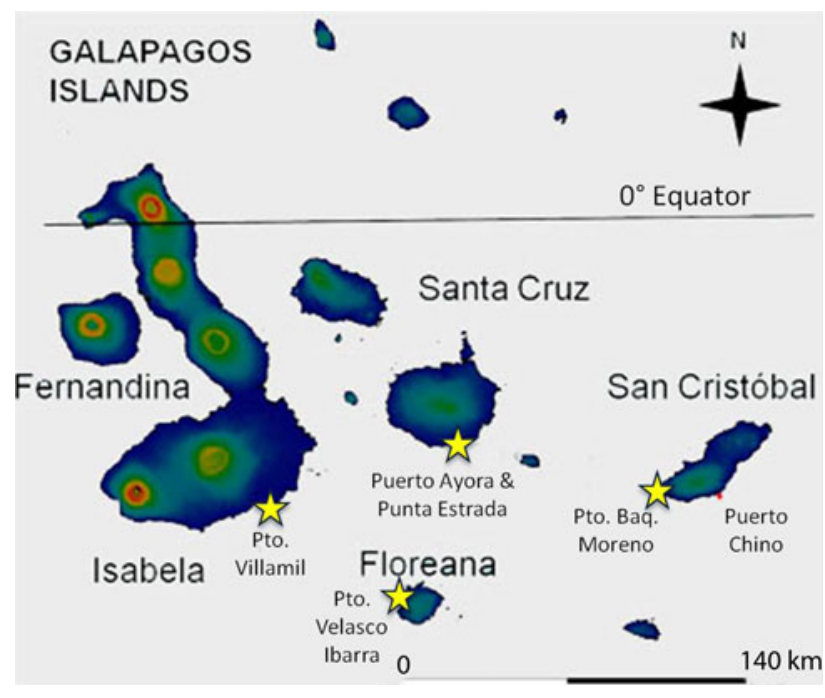

Figure 1. Map of water sampling locations on four islands in the Galápagos. Water sampling sites were primarily located near towns (stars) on inhabited islands. Floreana and Isabela have resident penguin colonies in and near town harbors, respectively. Flash flooding and surface runoff were observed on San Cristóbal \& Santa Cruz in 2010 in proximity to sampling sites. Color gradient indicates elevation from low (blue) to high (red) (Color figure online).

the Galápagos National Park, have been shown to have a high seroprevalence of T. gondii (Levy et al. 2008). Exposure to $T$. gondii has been documented in domestic chickens (Gottdenker et al. 2005), Galápagos penguins (Spheniscus mendiculus), and flightless cormorants (Phalacrocorax harrisi) in the archipelago (Deem et al. 2010). Clinical toxoplasmosis or mortality has not been observed in the Galápagos, but has been documented in avian species elsewhere (Dubey 2002) including in a Little Penguin (Eudyptula minor) (Mason et al. 1991), and naive island species can be highly susceptible (Work et al. 2000, 2002).

Galápagos penguins and flightless cormorants primarily live on Isabela and Fernandina (Vargas and Wiedenfeld 2004; Jiménez-Uzcátegui and Vargas 2008), islands separated by a narrow ocean channel less than $5-\mathrm{km}$ wide. Interestingly, $T$. gondii antibodies have been found in these species on both islands, despite a lack of cats on Fernandina (Deem et al. 2010). Galápagos penguins do move between islands within their range (Nims et al. 2008), but flightless cormorants remain within $1 \mathrm{~km}$ of shore and are distinct populations between islands (Duffie et al. 2009). Thus, exposure to $T$. gondii may be occurring by waterborne routes either directly through oocyst transport, or through prey such as fish that can act as mechanical vectors and migrate between islands (Miller et al. 2008; Massie et al.
2010). Similar to what has been described in other coastal ecosystems (Miller et al. 2002; Kreuder et al. 2003; Conrad et al. 2005), we propose that marine avifauna are being exposed to T. gondii oocysts via contaminated freshwater runoff. To evaluate this hypothesis, we collected fresh and estuarine water samples from islands with known cat populations and used membrane filtration and epifluorescent microscopy to analyze them for autofluorescent T. gondii oocysts (Lindquist et al. 2003). The utility of this simple and inexpensive approach for oocyst detection has been demonstrated under laboratory conditions (Shapiro et al. 2010), but has not been previously described in environmental samples. Our objectives were to test the field application of this new technique for detection of $T$. gondii oocysts on coastal surface waters of the Galápagos Islands and use this simple method to evaluate the potential for waterborne transmission of $T$. gondii to marine species within near-shore environments.

Water samples were collected from four islands (Santa Cruz, San Cristóbal, Isabela, and Floreana) during February 2010 at sites selected based on previous hydrological studies (Fig. 1) (d'Ozouville 2007, 2008; Pryet et al. 2012). At each site, a pump was used to collect $10 \mathrm{l}$ of water from the midwater column where fresh and saltwater mix. Water samples were qualitatively ranked using an ordinal scale of turbidity with 1 (clear), 2 (slightly turbid), and 3 (turbid/ opaque). Salinity, $\mathrm{pH}$, and temperature measurements were collected directly from the sampling location using a Multi 350i handheld water meter (WTW GmbH, Weilheim, Germany). In the laboratory, each 10-1 sample was siphoned into one liter aliquots and up to one liter per aliquot was filtered through a modified MicroFil ${ }^{\circledR}$ filtration funnel housing a $5-\mu \mathrm{m}$ pore size $25-\mathrm{mm}$ mixed cellulose membrane as described by Shapiro et al.(2010). For the most turbid samples (score 3), accumulation of debris on the membrane restricted filtration volumes. To determine the recovery rates of $T$. gondii oocysts, 200 autofluorescent microspheres, which have been validated as $T$. gondii surrogates (Shapiro et al. 2009), were spiked into one liter aliquots of water per turbidity score and similarly filtered. Membranes were then placed on a glass slide in duplicate, covered with glycerol mounting media and a cover slip, and stored at $4^{\circ} \mathrm{C}$.

The membranes were examined for $T$. gondii oocysts using a Nikon E800 Hyperspectral microscope with a UV emission filter set (DAPI: excitation 350/50×, emission 460/50 nm band pass filter; Chroma \#11000 v3). Structures similar to $T$. gondii oocysts were identified based on 
morphology and blue autofluoresence of the sporocyst and oocyst walls. Membranes that contained T. gondii oocystlike structures were further analyzed using nucleic acid extraction and polymerase chain reaction (PCR) analysis for T. gondii. Prior to DNA extraction, each membrane was suspended in $5 \mathrm{ml}$ de-ionized water and sonicated. Individual membrane suspensions were divided into three $1.5 \mathrm{ml}$ aliquots. Following centrifugation at 14,000 rpm for $10 \mathrm{~min}$, the supernatant was removed and the $25-\mu \mathrm{l}$ pellet remaining for each aliquot was subjected to one freezethaw cycle. DNA was extracted from each aliquot following a modified QIAamp DNeasy Blood and Tissue kit protocol (Qiagen) for tissue samples with $50 \mu \mathrm{l}$ of $95^{\circ} \mathrm{C}$ RNase and DNase-free sterile water was used in the final elution. Two nested PCR reactions were performed on each extraction sample (three aliquots per membrane) using $T$. gondiispecific primers (Homan primers) targeting a 200-300 copy repetitive element (Homan et al. 2000; Shapiro et al. 2010), and the 35 copy B1 gene (Grigg and Boothroyd 2001; Rejmanek et al. 2009). Positive controls [DNA extracted from Type II $T$. gondii tachyzoites in tissue cell pellets and oocysts (Shapiro et al. 2010)] and negative controls (PCR reagents and sterile water) were included in each reaction. Specific primer sequences, PCR reaction components, and thermocycler conditions are provided in supplemental Table 1. Amplification products from internal PCR reactions were separated by electrophoresis in a
2\% agarose gel and visualized by UV transillumination. Following purification with ExoSAP-IT ${ }^{\circledR}$, PCR products were submitted for sequence analysis at the University of California, Davis Division of Biological Sciences DNA Sequencing Facility. Complementary strand sequences were manually edited and assembled with CodonCode Aligner and compared to sequences in GenBank.

A total of $135 \mathrm{l}$ of water from 20 sites was filtered and analyzed by epifluorescent microscopy. Debris in the water samples variably affected the ability to visualize small fluorescent structures, such as autofluorescent oocysts (Fig. 2). Membranes from $50 \%$ of sites contained considerable debris (score 3), 35\% had moderate debris (score 2), and 15\% were relatively clear (score 1). Of the 100 membranes examined, two contained structures similar to $T$. gondii oocysts (Fig. 3). One suspect structure was seen on a membrane from San Cristóbal (Puerto Chino) and two suspect structures were seen on a membrane from Santa Cruz (Punta Estrada) (Table 1). These structures measured 5.3, 7.5, and $9.8 \mu \mathrm{m}$ in diameter, respectively. Recovery of surrogate microspheres in all samples was low, ranging from 3 to $4 \%$ for clear (score 1) to $1 \%$ for turbid water (score 3).

DNA was amplified from the two membranes containing suspect structures using Homan primers targeting the 200-300 copy repetitive element, but PCR amplification products were not consistent in size with $T$. gondii positive controls (Fig. 4). DNA was not amplified in aliquots from

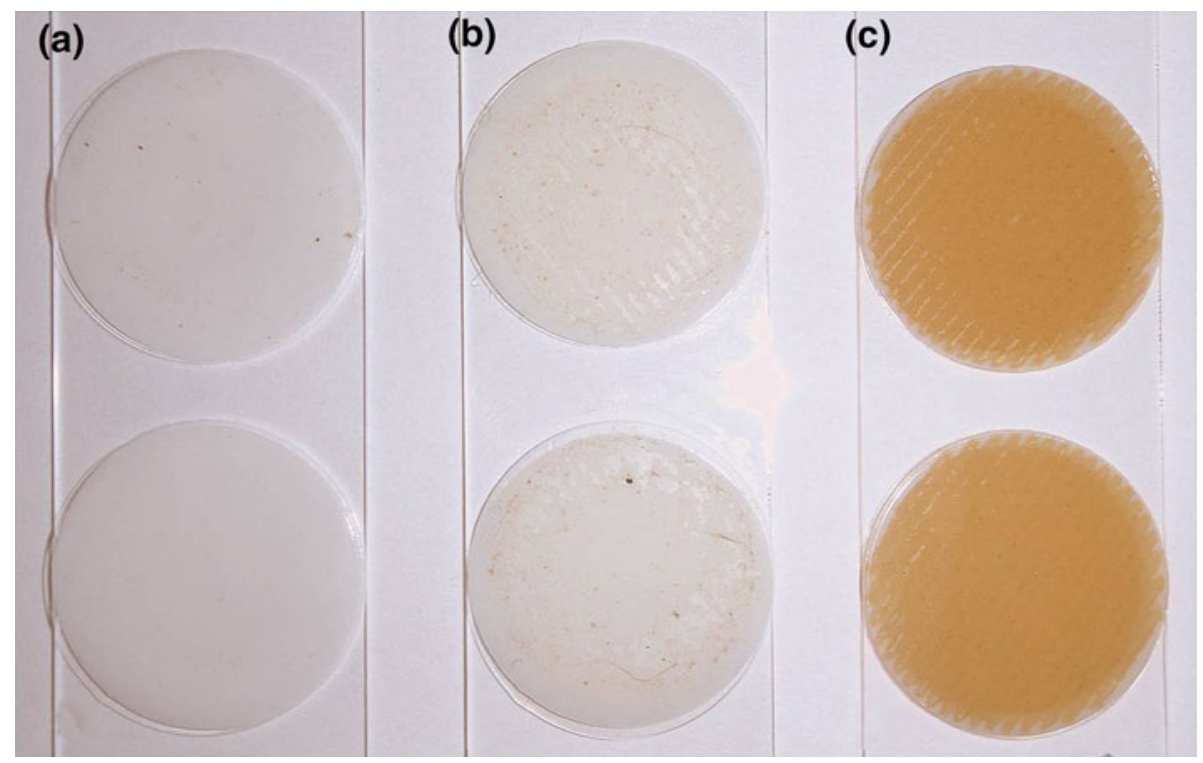

Figure 2. Comparison of membranes acquired from filtration of water samples of varying turbidity scores. Filtration of water samples through cellulose membranes produced variable amounts of debris on membranes. Representative duplicate membranes from water samples with subjective qualitatively ranked turbidity scores of 1 (a), 2 (b), and 3 (c) are shown. 
either sample using the B1 primers. Sequence analyses of PCR products produced a clean reverse primer sequence for the San Cristóbal sample, which was highly similar to unclassified marine metagenome samples recovered from surface waters near the Sargasso Sea, Panama Canal, and the Galápagos (GenBank: AACY024030902.1) and Ecuador (GenBank: EJ768524.1) (J Craig Venter Institute 2008). A clear sequence was not attainable from the Santa Cruz sample.

This study provides a preliminary investigation of waterborne transmission of $T$. gondii in the Galápagos Islands using a newly applied approach for T. gondii oocyst detection in environmental waters. Structures morphologically similar to T. gondii oocysts were observed by epifluorescent microscopy, but PCR and sequence analyses were negative for the parasite. Although these structures were smaller than the reference range for T. gondii oocysts (10$12 \mu \mathrm{m}$ ), apparent oocyst size and morphology can become altered under vacuum filtration, as is demonstrated by images of positive control $T$. gondii oocysts on filter membranes in Figure 3b, $c$ which are deformed and smaller than $10 \mu \mathrm{m}$. The small number of structures per membrane (1-2) may also have been insufficient to adequately amplify target DNA based on previous detection limits (Shapiro et al. 2010). Alternatively, these structures may have been similar autofluorescent apicomplexan parasites (Davies and Stewart 2000; Lindquist et al. 2003), non-pathogenic organisms, or debris of similar size and fluorescence.

Waterborne transmission of $T$. gondii and subsequent health risks have received considerable attention due to toxoplasmosis and mortality in marine wildlife (Kreuder et al. 2003; Conrad et al. 2005), as well as water-associated outbreaks in humans (Bowie et al. 1997; Jones and Dubey 2010). In addition, numerous other waterborne coccidian species, notably Cryptosporidium sp., Cyclospora cayetanensis, and other recently identified species, pose potential health risks for humans and marine wildlife (Reid et al. 2010; Baldursson and Karanis 2011; Carlson-Bremer et al.
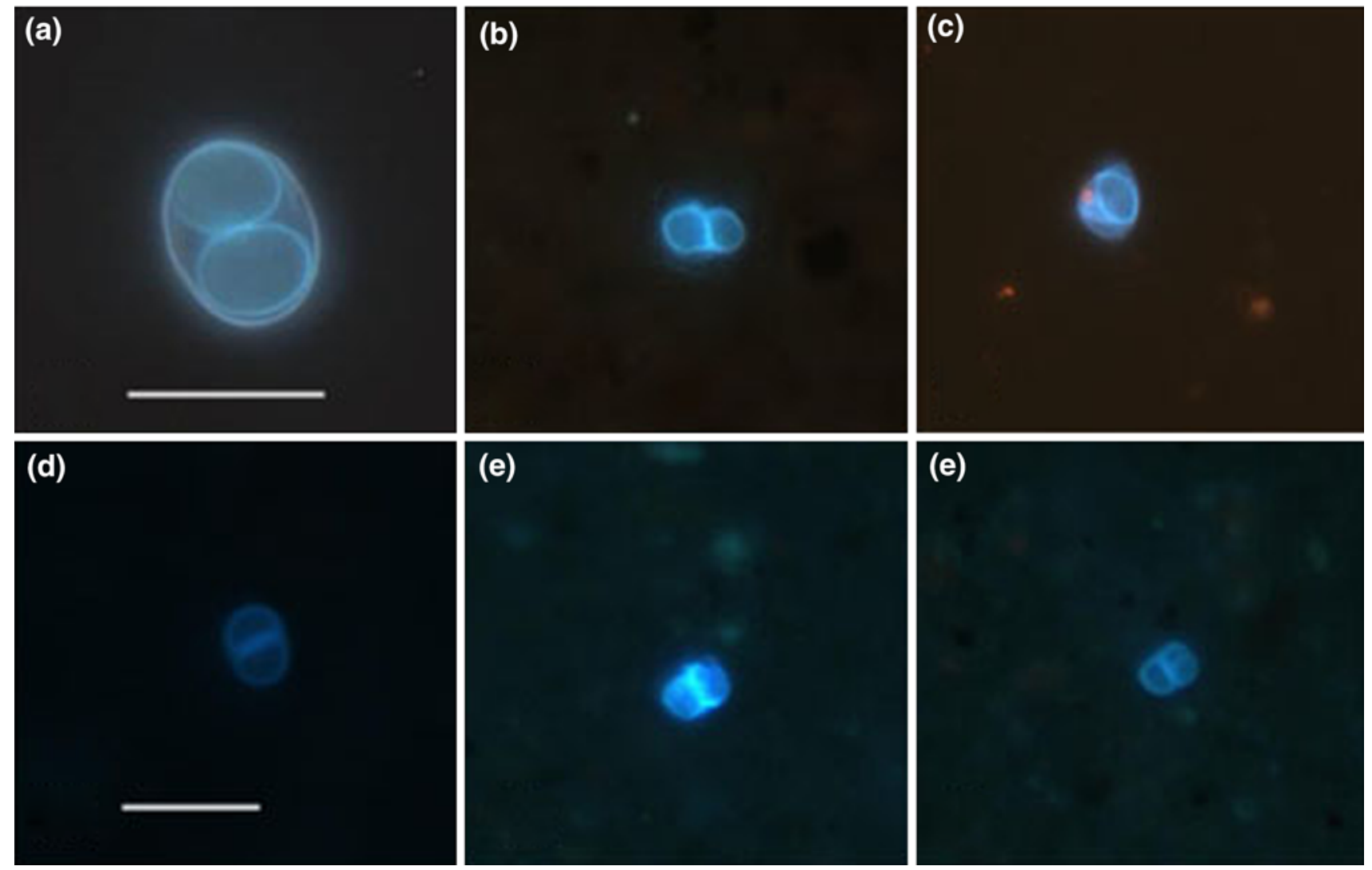

Figure 3. Appearance of T. gondii oocysts and oocyst-like structures visualized on filter membranes under epifluorescent microscopy. Toxoplasma gondii (Type II) oocysts (Shapiro et al. 2010) shown as positive controls at: (a) $\times 1000$ on a wet mount demonstrating characteristic morphology; and $(\mathbf{b}-\mathbf{c})$ at $\times 400$ on membranes depicting the distortion of typical morphology and size that can result from vacuum filtration. Oocyst-like structures observed on filter membranes from samples collected at (d) Puerto Chino and (e-f) Punta Estrada at $\times 400$. Structure sizes measured 5.3, 7.5, and $9.8 \mu \mathrm{m}$ in diameter, respectively. Scale bars represent $10 \mu \mathrm{m}$. 
Table 1. Site characteristics and test results for water sample locations.

\begin{tabular}{|c|c|c|c|c|}
\hline Island sample location & $\begin{array}{l}\text { Turbidity } \\
\text { score }(1-3)\end{array}$ & Salinity (ppt) & $\begin{array}{l}\text { Volume of water filtered (L) } \\
\text { Total per site/per membrane }\end{array}$ & $\begin{array}{l}\text { Number of oocyst-like } \\
\text { structures seen }\end{array}$ \\
\hline \multicolumn{5}{|l|}{ Floreana } \\
\hline Cana Parada & 2 & 34 & $10 / 1$ & 0 \\
\hline Finca El Trebol & 3 & 0 & $5 / 0.5$ & 0 \\
\hline Laguna de la & 2 & 32 & $10 / 1$ & 0 \\
\hline \multicolumn{5}{|l|}{ Montura } \\
\hline Punta Cormorant & 2 & 34 & $2.5 / 0.25$ & 0 \\
\hline \multicolumn{5}{|l|}{ Isabela } \\
\hline Concha la Perla & 2 & 25 & $10 / 1$ & 0 \\
\hline El Estero & 3 & 26 & $5 / 0.5$ & 0 \\
\hline El Estero outflow & 3 & 8 & $5 / 0.5$ & 0 \\
\hline Laguna Cuidad & 3 & 35 & $2.5 / 0.25$ & 0 \\
\hline Manzanillo & 1 & 0 & $10 / 1$ & 0 \\
\hline \multicolumn{5}{|l|}{ San Cristóbal } \\
\hline Cero Gato & 3 & 0 & $5 / 0.5$ & 0 \\
\hline La Policia & 3 & 0 & $5 / 0.5$ & 0 \\
\hline Puerto Chino & 2 & 17 & $10 / 1$ & $1^{\mathrm{a}}$ \\
\hline La Toma & 3 & 0 & $5 / 0.5$ & 0 \\
\hline Tongo Reef & 3 & 32 & $5 / 0.5$ & 0 \\
\hline \multicolumn{5}{|l|}{ Santa Cruz } \\
\hline El Baranco & 3 & 1 & $10 / 1$ & 0 \\
\hline El Baranco 2 & 2 & 0 & $10 / 1$ & 0 \\
\hline La Camiseta & 1 & 1 & $10 / 1$ & 0 \\
\hline Las Grietas & 2 & 24 & $10 / 1$ & 0 \\
\hline La Mision & 1 & 2 & $10 / 1$ & 0 \\
\hline Punta Estrada & 3 & 30 & $5 / .05$ & $2^{\mathrm{a}}$ \\
\hline
\end{tabular}

Structures morphologically similar to T. gondii oocysts were visualized using epifluorescent microscopy in samples from sites on Santa Cruz and San Cristóbal.

${ }^{\mathrm{a}}$ T. gondii not confirmed by PCR and sequence analyses.

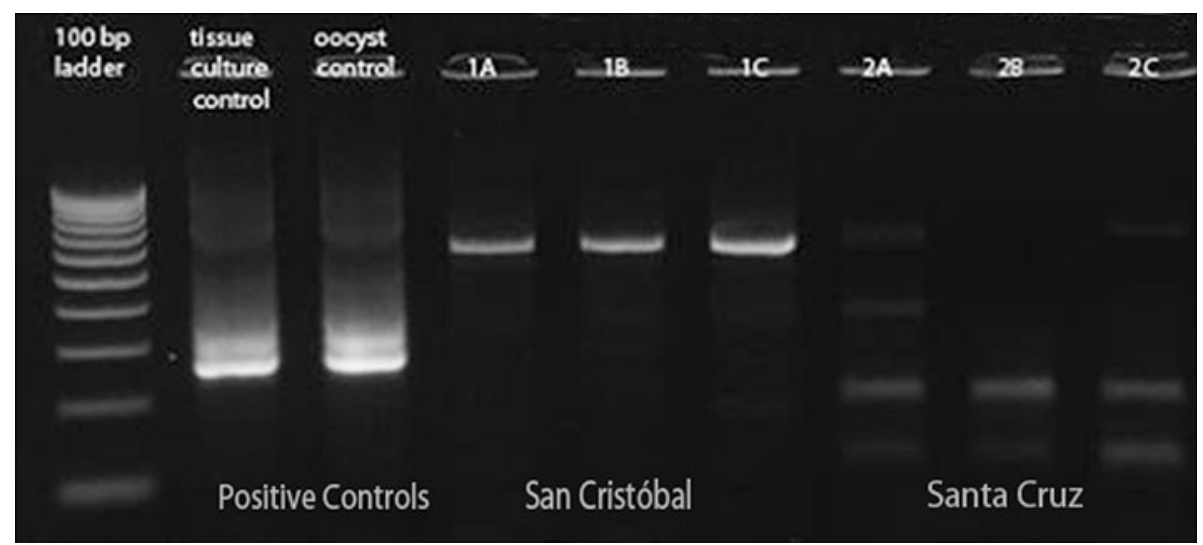

Figure 4. Gel electrophoresis of PCR amplified DNA products from membranes that contained structures resembling $T$. gondii oocysts. PCR analysis using Homan nested primers targeting a 200-300 copy repetitive element of $T$. gondii amplified DNA in the suspect membranes. However, amplicon sizes were not consistent with T. gondii positive controls (Type II isolate tachyzoites in tissue culture cells and oocysts). 
2011; Colegrove et al. 2011; Rengifo-Herrera et al. 2013). Several direct and molecular methods for oocyst detection in environmental samples have been described with variable success (Davies and Stewart 2000; Lindquist et al. 2003; Dumètre and Dardé 2005; Kourenti and Karanis 2006; Sotiriadou and Karanis 2008; Moulin et al. 2010; GallasLindemann et al. 2013; Karanis et al. 2013). It is clear from this work that detection of $T$. gondii and other coccidian oocysts in environmental water remains challenging due to likely low and highly variable oocyst concentrations, as well as inhibition by other water constituents.

Membrane filtration of water samples provides a relatively fast and inexpensive method for parasite concentration compared with other approaches that use capsule filtration followed by immunomagnetic separation (Dumètre and Dardé 2005) or sucrose gradient separation (Moulin et al. 2010). Under laboratory conditions, Shapiro et al. (2010) demonstrated the utility of this method following initial water filtration steps, and showed that subsequent analysis of the filter membranes using epifluorescent microscopy was more sensitive than conventional PCR for oocyst detection in both fresh and marine water. However, application of this method using membrane filtration as the sole means of parasite concentration for environmental water samples has not previously been described. The simple two-step process described here potentially offers a unique approach for detection of T. gondii and other autofluorescent coccidia in relatively isolated and resource limited locations such as, but not limited to, the Galapágos. The low recovery rates of surrogate microspheres and detection of $T$. gondii-like structures in this study suggest that modifications to more selectively preserve oocysts and increase removal of other water constituents may improve the effectiveness of this approach for environmental samples. These observations substantiate previous work that reported lower recovery rates in more complex sample matrices (Shapiro et al. 2010). In addition, the similarity in appearance among autofluorescent apixcomplexans such as Hemmondia, Neospora, Sarcocystis, and Besnoitia (Lindquist et al. 2003), can impede definitive identification and necessitates PCR and sequence analysis for confirmation.

Despite the lack of confirmation of T. gondii in the samples tested here, contamination of surface waters remains a plausible route for T. gondii exposure in marine avifauna of the Galápagos (Conrad et al. 2005; Deem et al. 2010). Feral domestic cats are frequently observed within coastal watersheds, including those with populations of penguins and cormorants (Vargas et al. 2006), and high volumes of surface runoff are known to occur, primarily during El NiñoSouthern Oscillation events (Glynn 1988; Trueman and d'Ozouville 2010; Violette et al. 2013). Specifically, the water sample collected at Puerto Chino was from a seasonal freshwater river that had formed following heavy rains 2 days prior and was delivering surface runoff directly into the ocean. Multiple feline scat piles were observed along the river bank during sample collection, and cats are known to be common in the area. Similarly, La Laguna at Punta Estrada is surrounded by residential development, and the area has an abundant cat population. Although the incidence of oocyst shedding among cats is generally low, one cat can shed up to 1 billion oocysts over several days following initial infection (Dubey and Frenkel 1972; Dubey 1995). Oocysts are incredibly resistant to environmental degradation and are known to survive in seawater for at least 2 years (Lindsay and Dubey 2009). Furthermore, unmanaged feral cats are associated with higher $T$. gondii prevalence and odds of oocyst shedding due to primary consumption of intermediate hosts (Konecny 1987; Afonso et al. 2007; VanWormer et al. 2013).

In a broader context, the zoonotic potential of T. gondii presents a public health concern for island residents and visitors. The incidence of toxoplasmosis and $T$. gondii seroprevalence in human communities in the Galápagos is unknown but likely high. Globally, highest infection rates of $T$. gondii are associated with rural areas, lower socioeconomic status, and drinking unfiltered water (Bahia-Oliveira et al. 2003). In the Galápagos Islands, fresh water is limited and the geologic structure of porous rock facilitates drainage and rapid mixing of surface and groundwater (Violette et al. 2013). Consequently, the overall lack of waste water treatment, unregulated groundwater pollution, and improper waste management practices are contributing to environmental pathogen pollution and health risks (González et al. 2008; Liu and d'Ozouville 2013). Understanding the epidemiology of toxoplasmosis and other waterborne diseases should be a top priority for protecting the health of wildlife and human communities, particularly in sensitive regions such as the Galápagos. Toward this goal, we suggest that further research is needed with refined environmental detection methods to evaluate pathogen exposure and disease risk.

\section{ACKNOWLEDGMENTS}

Thank you to the Saint Louis Zoo WildCare Center for Avian Health in the Galápagos Islands and the Charles 
Darwin Foundation for sponsorship of this project. Laboratory space, permit arrangements, and field assistance were provided by the Charles Darwin Foundation and the Galápagos National Park Directorate. This study was supported by the Morris Animal Foundation and the St. Louis Zoo's Field Research for Conservation program.

\section{REFERENCES}

Afonso E, Thulliez P, Pontier D, Gilot-Fromont E (2007) Toxoplamsosis in prey species and consequences for prevalence in feral cats: not all prey species are equal. Parasitology 134:19631971

Bahia-Oliveira LM, Jones JL, Azevedo-Silva J, Alves CC, Orefice F, Addiss DG (2003) Highly endemic, waterborne toxoplasmosis in north Rio de Janeiro state, Brazil. Emerging Infectious Diseases 9:55-62

Baldursson S, Karanis P (2011) Waterborne transmission of protozoan parasites: review of worldwide outbreaks - an update 2004-2010. Water Research 45:6603-6614

Bowie WR, King AS, Werker DH, Isaac-Renton JL, Bell A, Eng SB, et al. (1997) Outbreak of toxoplasmosis associated with municipal drinking water. The BC Toxoplasma Investigation Team. Lancet 350:173-177

Carlson-Bremer D, Johnson CK, Miller RH, Gulland FMD, Conrad PA, Wasmuth JD, et al. (2011) Identification of two novel coccidian species shed by California sea lions (Zalophus californianus). Journal of Parasitology 98:347-354

Colegrove KM, Grigg ME, Carlson-Bremer D, Miller RH, Gulland FMD, Ferguson DJP, et al. (2011) Discovery of three novel coccidian parasites infecting California sea lions (Zalophus californianus), with evidence of sexual replication and interspecies pathogenicity. Journal of Parasitology 97:868-877

Conrad PA, Miller MA, Kreuder C, James ER, Mazet J, Dabritz H, et al. (2005) Transmission of Toxoplasma: clues from the study of sea otters as sentinels of Toxoplasma gondii flow into the marine environment. International Journal for Parasitology 35:1155-1168

d'Ozouville N (2007) Fresh water in the Galapagos: the reality of a critic resource. CDF, SPNG, INGALA, Puerto Ayora, Santa Cruz, Galapagos, Ecuador.

d'Ozouville N, Deffontaines B, Benveniste J, Wegmuller U, Violette S, Marsily GD (2008) DEM generation using ASAR (ENVISAT) for addressing the lack of freshwater ecosystems management, Santa Cruz Island, Galapagos. Remote Sensing of Environment 112:4131-4147

Davies A, Stewart B (2000) Autofluorescence in the oocysts of marine and freshwater fish coccidia. Folia Parasitologica 47:157158

Deem S, Merkel J, Ballweber L, Vargas FH, Cruz M, Parker P (2010) Exposure to Toxoplasma gondii in Galapagos Penguins (Spheniscus mendiculus) and flightless cormorants (Phalacrocorax harrisi) in the Galapagos Islands, Ecuador. Journal of Wildlife Disease 46:1005-1011

Dubey J (1995) Duration of immunity to shedding of Toxoplasma gondii oocysts by cats. Journal of Parasitology 81:410-415

Dubey J (2002) A review of toxoplasmosis in wild birds. Veterinary Parasitology 106:121-153
Dubey J, Frenkel J (1972) Cyst-induced toxoplasmosis in cats. Journal of Eukaryotic Microbiology 19:155-177

Duffie CV, Glenn TC, Vargas FH, Parker PG (2009) Genetic structure within and between island populations of the flightless cormorant (Phalacrocorax harrisi). Molecular Ecology 18:21032111

Dumètre A, Dardé ML (2005) Immunomagnetic separation of Toxoplasma gondii oocysts using a monoclonal antibody directed against the oocyst wall. Journal of Microbiological Methods 61:209-217

Gallas-Lindemann C, Sotiriadou I, Mahmoodi MR, Karanis P (2013) Detection of Toxoplasma gondii oocysts in different water resources by loop mediated isothermal amplification (LAMP). Acta Tropica 125:231-236

Glynn PW (1988) El Nino Southern Oscillation 1982-1983: nearshore population, community, and ecosystem responses. Annual Review of Ecology and Systematics 19:309-345

González J, Montes C, Rodríguez J, Tapia W (2008) Rethinking the Galapagos Islands as a complex social-ecological system: implications for conservation and management. Ecology and Society 13:13

Gottdenker NL, Walsh T, Vargas H, Merkel J, Jiménez GU, Miller RE, et al. (2005) Assessing the risks of introduced chickens and their pathogens to native birds in the Galápagos Archipelago. Biological Conservation 126:429-439

Grigg ME, Boothroyd JC (2001) Rapid identification of virulent Type I strains of the protozoan pathogen Toxoplasma gondii by PCR-restriction fragment length polymorphism analysis at the B1 gene. Journal of Clinical Microbiology 39:398-400

Homan WL, Vercammen M, De Braekeleer J, Verschueren H (2000) Identification of a 200- to 300 -fold repetitive 529 bp DNA fragment in Toxoplasma gondii, and its use for diagnostic and quantitative PCR. International Journal for Parasitology 30:69-75

J Craig Venter Institute (2008) Global ocean sampling expedition. www.jvci.org. Accessed on June 5, 2011.

Jiménez-Uzcátegui G, Vargas F (2008) Censo del pingüino de Galápagos y Cormorán no volador. Estación Científica Charles Darwin, Puerto Ayora, Santa Cruz, Galapagos, Ecuador.

Jones JL, Dubey JP (2010) Waterborne toxoplasmosis: recent developments. Experimental Parasitology 124:10-25

Kaiser J (2001) Galápagos takes aim at alien invaders. Science 293:590-592

Karanis P, Aldeyarbi H, Mirhashemi M, Khalil K (2013) The impact of the waterborne transmission of Toxoplasma gondii and analysis efforts for water detection: an overview and update. Environmental Science and Pollution Research 20:86-99

Konecny MJ (1987) Food habits and energetics of feral house cats in the Galapagos Islands. Oikos 50:24-32

Kourenti C, Karanis P (2006) Evaluation and applicability of a purification method coupled with nested PCR for the detection of Toxoplasma oocysts in water. Letters of Applied Microbiology 43:475-481

Kreuder C, Miller MA, Jessup DA, Lowenstine LJ, Harris MD, Ames JA, et al. (2003) Patterns of mortality in southern sea otters (Enhydra lutris nereis) from 1998 to 2001. Journal of Wildlife Disease 39:495-509

Levy JK, Crawford PC, Lappin MR, Dubovi EJ, Levy MG, Alleman $\mathrm{R}$, et al. (2008) Infectious diseases of dogs and cats on Isabela Island, Galapagos. Journal of Veterinary Internal Medicine 22: 60-65 
Lindquist HD, Bennett JW, Hester JD, Ware MW, Dubey JP, Everson WV (2003) Autofluorescence of Toxoplasma gondii and related coccidian oocysts. Journal of Parasitology 89:865-867

Lindsay D, Dubey J (2009) Long-term survival of Toxoplasma gondii sporulated oocysts in seawater. Journal of Parasitology 95:1019-1020

Liu J, d'Ozouville N (2013) Water contamination in Puerto Ayora: applied interdisciplinary research using Escherichia coli as an indicator bacteria. GNPS, GCREG, CDF, and GC, Puerto Ayora, Santa Cruz, Galapagos, Ecuador.

Mason RW, Hartley WJ, Dubey JP (1991) Lethal toxoplasmosis in a little penguin (Eudyptula minor) from Tasmania. Journal of Parasitology 77:328

Massie GN, Ware MW, Villegas EN, Black MW (2010) Uptake and transmission of Toxoplasma gondii oocysts by migratory, filter-feeding fish. Veterinary Parasitology 169:296-303

Miller MA, Gardner IA, Kreuder C, Paradies DM, Worcester KR, Jessup DA, et al. (2002) Coastal freshwater runoff is a risk factor for Toxoplasma gondii infection of southern sea otters (Enhydra lutris nereis). International Journal for Parasitology 32:997-1006

Miller MA, Miller WA, Conrad PA, James ER, Melli AC, Leutenegger CM, et al. (2008) Type X Toxoplasma gondii in a wild mussel and terrestrial carnivores from coastal California: new linkages between terrestrial mammals, runoff and toxoplasmosis of sea otters. International Journal for Parasitology 38:1319-1328

Moulin L, Richard F, Stefania S, Goulet M, Gosselin S, Gonçalves A, et al. (2010) Contribution of treated wastewater to the microbiological quality of Seine River in Paris. Water Research 44:5222-5231

Nims BD, Vargas FH, Merkel J, Parker PG (2008) Low genetic diversity and lack of population structure in the endangered Galapagos penguin (Spheniscus mendiculus). Conservation Genetics 9:1413-1420

Nogales M, MartíN A, Tershy BR, Donlan CJ, Veitch D, Puerta N, et al. (2004) A review of feral cat eradication on islands. Conservation Biology 18:310-319

Pryet A, d'Ozouville N, Violette S, Deffontaines B, Auken E (2012) Hydrological settings of a volcanic island (San Cristobal, Galapagos) from joint interpretation of airborne electromagnetics and geomorphological observations. Hydrology and Earth System Science 16:4571-4579

Reid A, Lymbery A, Ng J, Tweedle S, Ryan U (2010) Identification of novel and zoonotic Cryptosporidium species in marine fish. Veterinary Parasitology 168:190-195

Rejmanek D, VanWormer E, Miller M, Mazet J, Nichelason A, Melli AC, et al. (2009) Prevalence and risk factors associated with Sarcocystis neurona infections in opossums (Didelphis virginiana) from central California. Veterinary Parasitology 3:8-14

Rengifo-Herrera C, Ortega-Mora LM, Gómez-Bautista M, GarcíaPeña FJ, García-Párraga D, Pedraza-Díaz S (2013) Detection of a novel genotype of Cryptosporidium in Antarctic pinnipeds. Veterinary Parasitology 191:112-118

Shapiro K, Largier J, Mazet JA, Bernt W, Ell JR, Melli AC, et al. (2009) Surface properties of Toxoplasma gondii oocysts and surrogate microspheres. Applied Environmental Microbiology 75:1185-1191

Shapiro K, Mazet JA, Schriewer A, Wuertz S, Fritz H, Miller WA, et al. (2010) Detection of Toxoplasma gondii oocysts and surrogate microspheres in water using ultrafiltration and capsule filtration. Water Research 44:893-903

Snell H, Tye A, Causton C, Bensted-Smith R (2002) Current status of and threats to the terrestrial biodiversity of Galapagos. In: A biodiversity vision for the Galapagos Islands. Charles Darwin Foundation and World Wildlife Fund, Puerto Ayora, Santa Cruz, Galapagos, Ecuador, pp 30-47.

Sotiriadou I, Karanis P (2008) Evaluation of loop-mediated isothermal amplification for detection of Toxoplasma gondii in water samples and comparative findings by polymerase chain reaction and immunofluorescence test (IFT). Diagnostic Microbiology and Infectious Disease 62:357-365

Trueman M, d'Ozouville N (2010) Characterizing the Galapagos terrestrial climate in the face of global climate change. Galapagos Research 67:26-37

VanWormer E, Conrad PA, Miller MA, Melli AC, Carpenter TE, Mazet J (2013) Toxoplasma gondii, source to sea: higher contribution of domestic felids to terrestrial parastie loading despite lower infection prevalence. EcoHealth . doi:10.1007/s10393-013-0859-x

Vargas F, Harrison S, Rea S, Macdonald D (2006) Biological effects of El Niño on the Galápagos penguin. Biological Conservation 127:107-114

Vargas F, Wiedenfeld D (2004) Summary report: 2004 penguin and cormorant survey, Oxford: Oxford University and Charles Darwin Foundation

Violette S, d'Ozouville N, Deffontaines B, Pryet A, Fortin J, Adelinet M (2013). Hydrogeology of the Galapagos Archipelago: an integrated and comparative approach between islands. In: Galapagos Islands: a natural laboratory for Earth Sciences. AGU Chapman Monograph Series

Wallace GD, Marshall L, Marshall M (1972) Cats, rats, and toxoplasmosis on a small Pacific island. American Journal of Epidemiology 95:475-482

Watkins G, Cruz F (2007) Galapagos at risk: a socioeconomic analysis of the situation in the archipelago. Charles Darwin Foundation, Puerto Ayora, Santa Cruz, Galapagos, Ecuador

Work TM, Massey JG, Lindsay D, Dubey JP (2002) Toxoplasmosis in three species of native and introduced Hawaiian birds. Journal of Parasitology 88:1040-1042

Work TM, Massey JG, Rideout BA, Gardiner CH, Ledig DB, Kwok OC, et al. (2000) Fatal toxoplasmosis in free-ranging endangered 'Alala from Hawaii. Journal of Wildlife Disease 36:205-212 